\title{
Przyjaciele Boga (gnostycy) - współdziałającymi w trudzie nabywania cnoty. Przyczynek do aretologii Klemensa Aleksandryjskiego
}

Szczegółowa analiza ${ }^{1} \mathrm{Klemensowej}^{2}$ definicji cnoty $(\dot{\alpha} \rho \varepsilon \tau \eta)^{3}$ pozwala określić ją mianem uporządkowanej osobowości, która jako harmonia wszystkich wartości, nie tylko cnót ${ }^{4}$, przynależnych do sfery intelektualnej, moralnej i egzystencjalnej człowieka $^{5}$, nieustannie dąży do jak najdoskonalszej jednomyślności z jej niedoścignionym wzorem - Boskim Logosem ${ }^{6}$, będącym Boską Cnotą, rozumianą jako

${ }^{1}$ Por. P. Szczur, Aretologia agapetyczna Klemensa Aleksandryjskiego w zarysie, „Roczniki Teologiczne” 48 : 2001, z. 4, s. 12-14; B. Zgraja, Klemensa Aleksandryjskiego koncepcja ópet̄́ (cnoty), „Studia Teologiczno-Historyczne Śląska Opolskiego” 29 : 2009, s. 211-227.

${ }^{2} \mathrm{Na}$ oznaczenie dzieł Klemensa użyto w przypisach skrótów: Paedagogus (dalej: Paed.), Stromata (dalej: Strom.), Quis dives salvetur? (dalej: QDS). Pozostałe skróty przytoczono według: Encyklopedia katolicka. Wykaz skrótów, Lublin 1993.

${ }^{3}$ Paed. I, 101, 2, SCh 70, s. 290 („Sama cnota jest dyspozycją duszy, będącą w zgodzie z Logosem przez cała życie" - tłum. własne).

${ }^{4}$ „Cnota” oznaczać będzie uporządkowaną osobowość, którą tworzy szereg wartości, w tym także i cnót. Klemens odchodzi bowiem od stoickiego rozumienia cnoty jedynie jako „nierozerwalnego łańcucha” cnót. Na temat stoickiej koncepcji cnoty pisze m.in. A. Swoboda, Stoicka koncepcja cnoty, „Symbolae Philologorum Posnaniensium Graecae et Latinae” 12 : 1998, s. 31-41.

${ }^{5}$ Zagadnienie sfer omawia F. Drączkowski, Kościót-Agape wedtug Klemensa Aleksandryjskiego, Lublin 1983, s. 76-88.

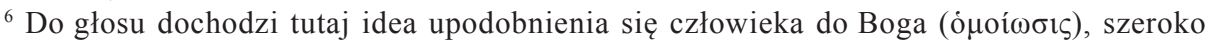
eksponowana w filozofii platońskiej, a potem w stoickiej, która jako wyraźnie chrześcijańska stała się

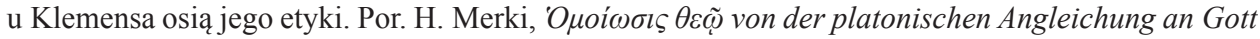
zur Gottähnlichkeit bei Gregor von Nyssa, Freiburg in der Aschweiz 1952, s. 44-45; M. Berciano, Kairós. Tiempo humano e histórico-salvifice en Clemente de Alejandría, Madrid 1976, s. 212, 251; J. Daniélou, Message Evangélique et Culture Hellénistique aux II et III ${ }^{e}$ siècles, Tournai 1961, s. 375; J. Pałucki, Recepcja ideałów helleńskich w nauce Klemensa Aleksandryjskiego, ,Roczniki TeologicznoKanoniczne" 41 : 1994, z. 4, s. 19. 
doskonała harmonia (agape) w sprawach przynależnych do kręgu intelektualnego, moralnego i egzystencjalnego. Jak zatem widać, cnota, czyli w rozumieniu Klemensa nieustannie doskonalona przez człowieka na wzór Boskiego Logosu - Chrystusa ${ }^{8}$ uporządkowana osobowość, jest dziełem Bosko-ludzkim. W całym procesie nabywania cnoty udział Boskiego Logosu - Chrystusa nie sprowadza się jednak tylko do pełnienia roli jej wzorca9. W nauczaniu Aleksandryjczyka Chrystus jest bowiem przede wszystkim Lekarzem, Pedagogiem i Nauczycielem niosącym pomoc tym wszystkim, którzy pragną osiągnąć jak najdoskonalszą cnotę. Jego działalność ${ }^{10}$, stanowiąca o Boskim charakterze kształtowania uporządkowanej osobowości ${ }^{11}$, jest ważną, choć nie jedyną formą pomocy wspierającej trud zabiegającego o jak najlepsze odwzorowanie w sobie, na wzór Boskiego Logosu, obecnej w Nim harmonii wszystkich wartości przynależnych do sfery intelektualnej, moralnej i egzystencjalnej. Dążącego do jak najdoskonalszej jednomyślności owych sfer z Boskim Logosem, a więc krótko mówiąc do cnoty, wspiera bowiem także gnostyk, którego działalność uzupełnia tym samym pojęcie wymiaru ludzkiego całego procesu jej nabywania, utożsamianego często jedynie z tym, który kształtując w sobie doskonałą cnotę, zmuszony jest do realizacji konkretnych zadań gwarantujących jej osiągnięcie. Niestety, ten ważny, jak się wydaje skądinąd, aspekt wymiaru ludzkiego procesu nabywania cnoty jest prawie nieobecny $\mathrm{w}$ analizach podejmowanych przez badaczy myśli Klemensa ${ }^{12}$. Zasadne wydaje się więc podjęcie tej tematyki w niniejszym

${ }^{7} \mathrm{O}$ ile można w ogóle mówić o istnieniu jakichś sfer w Bogu. Por. E. Stauffer, $\dot{\alpha} \gamma \alpha \pi \alpha \dot{\omega} \omega, \dot{\alpha} \gamma \alpha \dot{\pi} \eta$, ג̇ $\alpha \pi \eta \tau o ́ \varsigma$, , [w:] Theologisches Wörterbuch zum Neuen Testament, t. 1, red. G. Kittel, G. Fiedrich, Stuttgart 1933, s. 53.

8 „Boski Logos” jest podstawowym tytułem, jakim Klemens określa Chrystusa. Por. W. Kelbert, Die Logoslehre. Von Heraklit bis Origenes, Stuttgart 1976, s. 179-216.

${ }^{9}$ Por. Strom. II 19, 1, GCS 52, s. 122.

${ }^{10}$ Działania Chrystusa podyktowane są stopniem zaawansowania człowieka w procesie nabywania cnoty. Występując w roli Lekarza, Chrystus, który jako środek leczniczy stosuje kary i nagany, stara się, by Jego działalność doprowadziła do nawrócenia, przyjęcia wiary i do walki z grzechami ciężkimi oraz nałogami. Jako Pedagog, zachęca z kolei do ćwiczenia się w wypełnianiu przykazań i pełnienia dobra, w czym pomóc mają stosowane przez Niego środki mobilizujące, jakimi są doradzanie, obietnica szczęścia oraz zachęta. Jako Nauczyciel, Chrystus, nauczając za pośrednictwem filozofii greckiej, Prawa, Proroków, Tradycji i nauki Kościoła, doprowadza człowieka przede wszystkim do poznania Boga, przez co następuje harmonia z Bogiem w sferze intelektualnej, która razem ze zharmonizowanymi dzięki działalności Boskiego Lekarza i Pedagoga, sferami moralną i egzystencjalną, zbliżają człowieka do ideału uporządkowanej osobowości - Boskiej Cnoty. Więcej na ten temat zob. B. Zgraja, Chrystus boski logos - wzór i mistrz cnoty wedtug Klemensa Aleksandryjskiego, „Studia Warmińskie” 47 : 2010 , s. 51-69.

${ }^{11}$ Por. W. Bierbaun, Geschichte als Paidogogia Theou. Ein Beitrag zur Interpretation des Klemens von Alexandrien, „Münchener Theologische Zeitschrift” 5 : 1954, s. 256.

${ }^{12}$ Dotychczasowe studia nad pojęciem ,,cnoty” u Klemensa koncentrowały się głównie na problemie jej zależności od systemów filozoficznych. Por. m.in. S. R. C. Lilla, Clement of Alexandria. A Study in Christian Platonism and Gnosticism, Oxford 1971, s. 60-117; J. Ferguson, The Achievement of Clement of Alexandria, „Religious Studies” 12 : 1976, s. 59-80 ; W. Völker, Der wahre Gnostiker nach Clemens Alexandrinus, Berlin 1957, s. 449-479. Jedynie F. Drączkowski, omawiając cnotę agape, 
artykule, którego pierwsza część ukazująca związany z jej nabywaniem trud ma uzmysłowić konieczność pomocy, jaką niesie w procesie jej tworzenia jako dzieła Bosko-ludzkiego nie tylko Chrystus-Boski Lekarz, Wychowawca i Nauczyciel, ale także przyjaciel Boga, czyli gnostyk.

\section{„Cnota mieszka hen, na niedostępnych skałach”}

Zdaniem Klemensa „cnota nie jest nam wrodzona w sposób naturalny, ani nie przysługuje nam od narodzin jak jakieś inne części ciała”"13, a jej uzyskanie „nie zależy od niczego innego, jak wyłącznie od nas samych"14. Istnieje więc, jak mówi

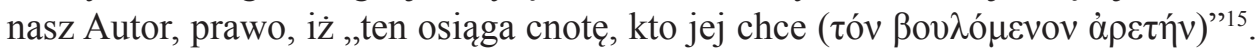
Wypada w tym miejscu zauważyć, że wartość semantyczna użytego tutaj czasownika

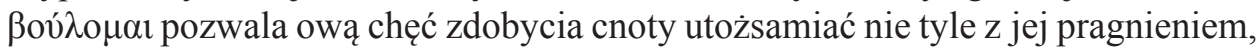
ile wręcz z pożądaniem ${ }^{16}$. Pożądanie cnoty nie jest jednak pozbawione elementu racjonalnego. Rdzeń $\beta$ ov $\lambda$-, jak również jego odpowiednik w formach doryckich

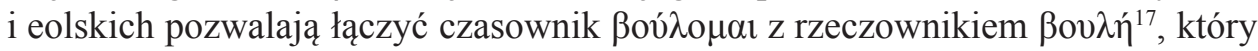
oprócz chęci, woli, decyzji, oznacza także radę, zamysł, zamiar, plan oraz rozważenie i rozpatrzenie ${ }^{18}$. Uwagi te prowadzą zatem do wniosku, iż u podstaw wolnej decyzji zabiegania o cnotę leży szeroko pojęta refleksja nad nią samą, która możliwa „dzięki możności myślenia, poznawania i przewidywania”19 , każe „brać w rachubę tylko to, co prawdziwe, co wzniosłe, co sprawiedliwe, co święte, co godne miłości, co chlubne, czy to jest cnota, czy coś zasługującego na pochwałę"20, „kierując się w swoim postępowaniu względem na pożytek, który do cnoty prowadzi albo z cnoty wychodzi” ${ }^{21}$. Owocem owej refleksji jest przekonanie, że „nie samo białe srebro albo złoto jest dla ludzi wszak rzeczą cenną, ale cnota też"22, która ponadto stanowi

wspomina o „leczniczej, wychowawczej i nauczycielskiej” działalności gnostyka, pełnionej w ścisłym zjednoczeniu z Chrystusem. Por. F. Drączkowski, Kościót-Agape...., s. 155. Z kolei P. Szczur wśród czynników warunkujących zdobycie cnoty wymienia jedynie właściwości wrodzone, kształcenie i ćwiczenie oraz łaskę. Por. P. Szczur, Vetera et nova w koncepcji aretologii Klemensa Aleksandryjskiego, „Roczniki Teologiczne” 53 : 2006, z. 4, s. 93-98.

${ }^{13}$ Strom. VII 19, 3, GCS 17, s. 14, Klemens Aleksandryjski, Kobierce zapisków filozoficznych dotyczacych prawdziwej wiary (księgi I-VII), thum. J. Niemirska-Pliszczyńska, t. 2, Warszawa 1994, s. 230 (dalej: Kobierce).

${ }^{14}$ Strom. IV 124, 1, GCS 52, s. 303, Kobierce, t. 1, s. 366.

${ }^{15}$ Strom. VII 9, 4, GCS 17, s. 8, Kobierce, t. 2, s. 224. Por. Strom. II 12, 1, GCS 52, s. 119.

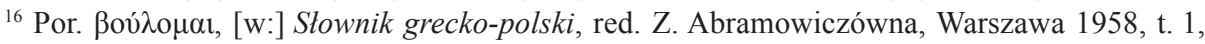
s. 438 (dalej: Abramowiczówna).

${ }^{17}$ Por. tamże.

${ }^{18}$ Por. tamże.

${ }^{19}$ Strom. VII 46, 9, GCS 17, s. 35, Kobierce, t. 2, s. 254.

${ }^{20}$ Strom. III 109, 3, GCS 52, s. 246, Kobierce, t. 1, s. 294.

${ }^{21}$ Strom. VII 59, 5, GCS 17, s. 43, Kobierce, t. 2, s. 265.

${ }^{22}$ Strom. IV 24, 6, GCS 52, s. 259, (tłum. własne). Por. Eurypides, Oedipius, Fragm. 542. 
o pięknie duszy ${ }^{23}$. Jako taka staje się więc cnota przedmiotem godnym pożądania, mobilizującym do działań prowadzących do jej nabycia, do podjęcia których może jednak zniechęcić, uzyskana w refleksji nad nią, dzięki wspomnianej zdolności przewidywania, świadomość trudu związanego z jej nabywaniem. Mimo wszystko, możemy jednak powiedzieć, że cnota jawi się nam jako wartość, która „nie powstaje z okoliczności zewnętrznych"24, lecz nabywana jest w pełni świadomie $(\gamma v \omega \sigma \tau \kappa \kappa \tilde{\sigma} \sigma)^{25}$.

O trudzie związanym z jej nabywaniem, będącym z pewnością, jak to już zostało zasygnalizowane, także owocem refleksji nad samą cnotą, świadczy przytoczona przez Klemensa poetycka opowieść Symonidesa o cnocie mieszkającej na niedostępnych skałach:

Słusznie zatem pisze Symonides: istnieje opowieść, że cnota mieszka hen, na niedostępnych skałach, orszak zaś święty rączych nimf otacza ją wkoło. Widok to nie dla oczu wszystkich ludzi

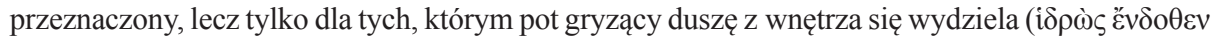
$\mu o ́ \lambda \eta)$ odwaga zaś dosięga szczytu ${ }^{26}$.

Ogrom tego trudu, z racji - używając poetyckiego języka Symonidesa - jej zamieszkiwania na niedostępnych skałach w otoczeniu świętych nimf, obrazuje także w jakimś stopniu analiza semantyczna niektórych form czasownikowych, które na język polski zostały przetłumaczone przez „dążyć do cnoty” ( $\sigma \pi \varepsilon v \delta \varepsilon ́ \tau \omega$

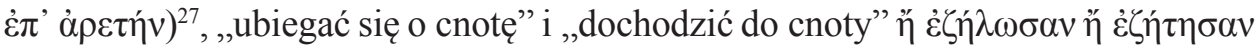

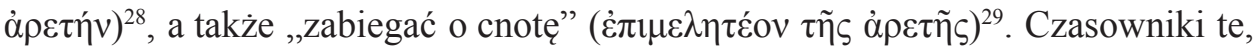
co oddają równie dobrze polskie tłumaczenia, wskazują przede wszystkim na trud, jaki niesie z sobą szeroko rozumiana aktywność, która winna cechować wszystkich dążących do cnoty. Szczególnie wymowny w tym względzie jest czasownik $\zeta \eta \lambda o ́ \omega^{30}$, który dopełnia, jak się wydaje, możliwy do zarysowania w oparciu o wartości semantyczne czasowników $\sigma \pi \varepsilon v ́ \delta \omega^{31}$ oraz غ̇ं $\mu \mu \varepsilon \lambda \varepsilon \dot{\varepsilon} 0 \mu \alpha 1^{32}$, obraz trudu, a tym samym i zaangażowania dążącego do cnoty, każąc widzieć cały proces jej nabywania niejako w kategoriach współzawodnictwa, opartego na zazdrosnym pożądaniu zwycięstwa. Co więcej, użyta przez Klemensa w odniesieniu do procesu nabywania cnoty forma

${ }^{23}$ Por. Strom. V 97, 5, GCS 52, s. 390. Por. Platon, Protagoras 309 c-d.

${ }^{24}$ Strom. VII 19, 3, GCS 17, s. 14, Kobierce, t. 2, s. 231.

${ }^{25}$ Por. Strom. II 80, 3, GCS 52, s. 155.

${ }^{26}$ Strom. IV 48, 3-4, GCS 52, s. 271, Kobierce, t. 1, s. 324. Por. Symonides, Fragm. 37.

${ }^{27}$ Strom. IV 123, 2, GCS 52, s. 303, Kobierce, t. 1, s. 365-366.

${ }^{28}$ Paed. III 42, 1, SCh 158, s. 92.

${ }^{29}$ Strom. IV 59, 3-4, GCS 52, s. 275, Kobierce, t. 1, s. 330.

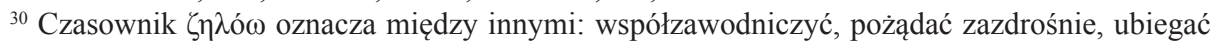
się gorliwie. Por. Abramowiczówna, t. 2, s. 398.

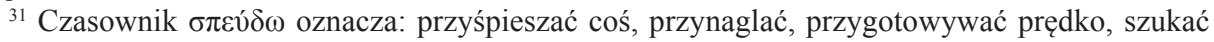
skwapliwie, spieszyć się, pędzić, gnać, czynić wysiłki, starać się usilnie. Por. tamże, t. 4, s. 87.

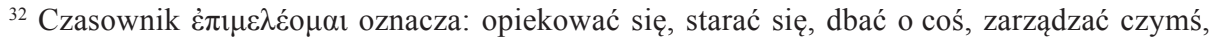
dokładać starań, zatroszczyć się, mieć coś pod opieką, być opiekunem lub stróżem, zajmować się, uprawiać. Por. tamże, t. 2, s. 251-252. 


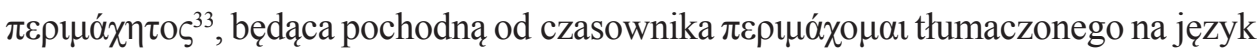
polski jako „walczyć” oraz „atakować ze wszystkich stron”34, zdaje się najpełniej obrazować trud i zaangażowanie człowieka dążącego do jak najdoskonalszej cnoty, porównując je do wysiłku związanego z bojem, jaki toczą z sobą wrogie oddziały wojsk ${ }^{35}$. Nic zatem dziwnego, że podjęcie przez człowieka, ze świadomością czekającego go trudu, zamiaru zdobywania cnoty ${ }^{36}$, będącego, jak mówi Klemens, świętą decyzją wyboru (

Trudu, jaki towarzyszy nabywaniu cnoty, będącego z pewnością często źródłem zniechęcenia w kroczeniu obraną drogą prowadzącą do jej osiągnięcia, nie należy jednak utożsamiać z wysiłkiem fizycznym. Użyte przez Symonidesa poetyckie wyrażenie: „pot gryzący duszę z wnętrza się wydziela” oznacza bowiem trud związany z kierowaniem się w życiu określonymi przez Prawo Boże zasadami etycznymi, które wyznaczają ,,wąską i ciasną” drogę, prowadzącą do zdobycia cnoty. Za taką interpretacją Symonidesowego wyrażenia zdaje się przemawiać następująca wypowiedź naszego Autora:

Oto Ewangelia i Apostołowie, a także wszyscy zgoła Prorocy, stawiają nam przed oczyma dwie drogi. Jedną nazywają „,wąską i ciasną”, a prowadzi ona przez przykazania i zakazy. Drugą natomiast, wiodącą na zatracenie, nazywają „,szeroką i przestrzenną”, i dostępna jest ona dla rozkoszy i namiętności. I mówią: „Szczęśliwy mąż, który nie podąża za radą bezbożnych i nie wkroczył na drogę grzeszników”. Istnieje też opowieść Prodikosa z Keos o Cnocie i Nieprawości ${ }^{38}$.

Wynika z niej, że spośród dwóch dróg przedstawionych w Prawie, wąskiej i szerokiej ${ }^{39}$, tylko ta pierwsza, choć niewygodna i niełatwa, bo ograniczona przez przykazania i zakazy, prowadzi do celu - cnoty. Potwierdzeniem słuszności takiego rozumowania, a zarazem uzasadnieniem wyboru tej drogi jest, przywołana przez Klemensa w tym kontekście, opowieść Prodikosa o Cnocie i Nieprawości ${ }^{40}$. Cnota, czyli Niewiasta o poważnym obliczu, zachęca, jak mówi Prodikos, do kroczenia drogą wąską i ciasną, która prowadzi do trwałego szczęścia i nieśmiertelności, będących owocami osiągniętej w ten sposób cnoty ${ }^{41}$. Jednocześnie Prawo nie tyle przestrzega przed wyborem drugiej drogi - szerokiej, ,dostępnej dla rozkoszy i namiętności”, co wręcz poleca odrzucić, jak czytamy w Stromacie II, wszystko to,

${ }^{33}$ Strom. IV 69, 1, GCS 52, s. 279.

${ }^{34}$ Por. Abramowiczówna, t. 3, s. 499.

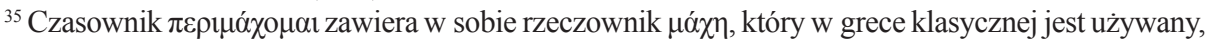
gdy mówi się o wojnie pomiędzy narodami. Por. H. Menge Altgriechisch-Deutsch Taschenwörterbuch, Berlin 1986, s. 282.

${ }^{36}$ Por. Strom. IV 49, 1, GCS 52, s. 270.

${ }^{37}$ Strom. VII 48, 1, GCS 17, s. 36.

${ }^{38}$ Strom. V 31, 1-2, GCS 52, s. 347, Kobierce, t. 2, s. 28-29.

${ }^{39}$ Por. Mt 7, 13; Łk 13, 24.

${ }^{40}$ Por. Prodikos, Fragm. 2; Xenophon, Memorabilia II 1, 21-34; Cicero, De officiis I, 32, 118; Philo, De sacrificiis Abelis et Caini, 20-33.

${ }^{41}$ Por. Strom. V 97, 6, GCS 52, s. 390; II 133, 7, GCS 52, s. 186-187; II 131, 5, GCS 52, s. 185 ; II 133, 5, GCS 52, s. 186. 
„co jest złe z samej swej istoty, a mianowicie: cudzołóstwo, rozwiązłość, pederastię, brak świadomości moralnej, zadawanie krzywd oraz śmierć jako chorobę duszy, która oddziela duszę od prawdy" ${ }^{42}$. Tak bowiem rozumiana szeroka droga, niczym Niewiasta ze wspomnianej opowieści Prodikosa, kusi zapewnieniami trwałego szczęścia, lecz w rzeczywistości, jak mówi Prawo, prowadzi do zatracenia ${ }^{43}$. Jedynie zatem trzymanie się w życiu określonych Prawem zasad etycznych jest właściwym sposobem życia, zapewniającym osiągnięcie cnoty.

Trud towarzyszący nabywaniu cnoty, wynika także z konieczności kroczenia po drodze długiej, stromej, a zarazem i nierównej:

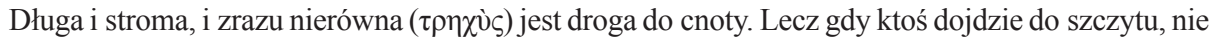

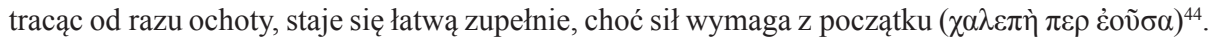

Co więcej, droga ta jest możliwa do podjęcia tylko przez gwałtowników $(\beta 1 \alpha \sigma \tau \tilde{\omega} v)^{45}$. Wypada jednak zauważyć, że nierówność tej drogi, wyrażona greckim terminem $\tau \rho \eta \chi v ́ \varsigma$, który zapowiada ogrom ludzkich zmagań dla podążających drogą cnoty ${ }^{46}$, sprawia, iż droga ta może wydawać się nie tyle trudna, ile często wręcz niemożliwa $(\chi \alpha \lambda \varepsilon \pi \text { ó } \varsigma)^{47}$ do przebycia. Rodzące się, jak się wydaje, z owego przekonania zniechęcenie ${ }^{48}$, wymaga zaś od zainteresowanych nabyciem cnoty ${ }^{49}$ nieustannego pokonywania trudu, jaki niesie wręcz przymuszanie $\operatorname{się}^{50}$ do podejmowania stosownych

${ }^{42}$ Strom. II 34, 2, GCS 52, s. 130-131, Kobierce, t. 1, s. 152.

${ }^{43}$ Por. Mt 7, 13; Ps 1, 6; Prz 12, 28.

${ }^{44}$ Strom. IV 5, 2, GCS 52, s. 251, Kobierce, t. 1, s. 299. Por. Hesiodus, Opera et dies, 289-292.

${ }^{45}$ Strom. IV 5, 3, GCS 52, s. 252.

${ }^{46}$ Termin $\tau \rho \alpha \chi$ v̀ s przybiera następujące znaczenia: 1) chropowaty, chropawy, szczerbaty, szorstki; skalisty; kamienisty; szorstki w dotknięciu, ostry, najeżony; kłujący, cierpki, włochaty; 2) nierównomierny, burzliwy, wzburzony; 3) o dźwiękach: szorstki, ochrypły, rażący; 4) o stylu: szorstki, chropowaty; 5) o walce: okrutny, zacięty, ciężki; 6) o charakterze: szorstki, opryskliwy, gburowaty; dziki; ostry, twardy, okrutny; gwałtowny, popędliwy. Por. Abramowiczówna, t. 4, s. 345.

${ }^{47}$ Taką interpretację wydaje się dopuszczać przymiotnik $\chi \alpha \lambda \varepsilon \pi$ ós, który oznacza: trudny, 1) o uczuciach: trudny do zniesienia, bolesny, dotkliwy, przykry, uciążliwy; 2) trudny do wykonania, mozolny, ciężki; trudne, wszelako nie niemożliwe; 3) niebezpieczny; 4) trudny do przebycia, szorstki, nierówny, niedostępny; 5) o osobach: taki, z którym trudno jest utrzymywać stosunki, nieprzystępny, okrutny, surowy, srogi, zły; z dat. pers. okrutny, przykry, ostry względem kogoś; o słowach: przykry, obelżywy; o sędziach: surowy; źle usposobiony, gniewliwy; o zwierzętach: dziki, wściekły, zły; złośliwy - o pszczołach; 7) o roślinach: szkodliwy dla gleby. Por. tamże, s. 586.

${ }^{48}$ Zniechęcenie może być z pewnością także powodowane samą długością procesu nabywania cnoty.

${ }^{49}$ Zainteresowanych, a więc tych, którzy mają zamiar wejść na drogę cnoty, jak i tych, którzy już podążają jej drogą.

${ }^{50} \mathrm{Klemens}$, posługując się terminem $\beta 1 \alpha \sigma \tau \grave{s}$, nazywa zdobywających cnotę gwałtownikami. Termin

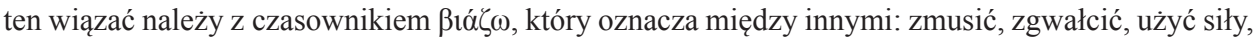
być naciskanym, nękanym, być zmuszonym, opanować siłą, przycisnąć, podnieść rękę na siebie, zmusić kogoś do czegoś, wymóc, wykonać siłą. Por. tamże, t. 1, s. 424. Działanie gwałtownika w kontekście nabywania cnoty thumaczyć zatem należałoby jako osobiste przymuszanie się do dalszego kroczenia wybraną drogą. 


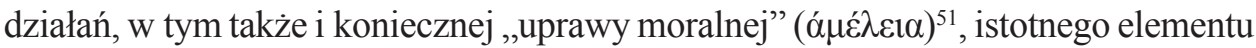
całego procesu nabywania cnoty, których to brak skutkuje popadnięciem w zupełne jej przeciwieństwo ${ }^{52}$. Zaniechanie koniecznych działań prowadzących do nabycia cnoty wynika jednak często nie tyle ze zniechęcenia powodowanego długotrwałym wysiłkiem, czy też przekonaniem o niemożliwości osiągnięcia cnoty, co ze zmiany oceny jej wartości, dokonywanej nierzadko pod wpływem nawet najbliższego otoczenia. Klemens zaleca więc, by nawet żona, która będąc posłuszna we wszystkim mężowi, samodzielnie dokonywała podstawowych ocen cnoty, i jeśli to konieczne - sama także o nią zabiegała ${ }^{53}$. Co więcej, ubiegający się o cnotę, mając na uwadze szansę wykonania czynu moralnie pięknego - jednego z czynników warunkujących jej osiągnięcie, nie powinien liczyć się z aprobatą czy dezaprobatą otoczenia. W przekonaniu bowiem Aleksandryjczyka, „,nie należy iść za poglądami tłumu, gdyż są one bałamutne i pełne sprzeczności" "54. Można więc stwierdzić, konkludując powyższe rozważania, że trud związany z dążeniem do cnoty wynika nie tylko z konieczności dochowywania wierności Bożym nakazom. Jego źródła należy także upatrywać w pokonywaniu zniechęcania, jakie przynoszą: nieustanna wierność Bożym poleceniom, długotrwały proces jej nabywania, przekonanie o niemożliwości jej osiągnięcia, jak również podejmowanie po raz kolejny zaprzestanej „uprawy moralnej”, czy innych stosownych działań, zaniechanych nierzadko pod wpływem opinii otoczenia.

Wypada jednak dodać, że trud nabywania cnoty winien być łączony z przekonaniem, iż Bóg nie pozostawia człowieka samego, a co za tym idzie, nie skazuje go tylko na przyrodzone siły umysłu, lecz wspiera mocą nadprzyrodzoną, która „tchnie coś w myśli i obliczenia ludzi, wzmacnia siłę ich umysłu i zaostrza zdolność postrzegania, dodając zachęty w postaci zuchwałej odwagi ich poszukiwaniom i czynom"55. Przywołany tutaj ważny element procesu nabywania cnoty - element łaski ${ }^{56}$, oprócz wspomnianej już pomocy, jaką świadczy dążącemu do niej Chrystus Lekarz, Pedagog i Wychowawca, uzupełnić jednak należy jeszcze jednym obszarem Bożej aktywności. Jak bowiem czytamy w Stromacie VI, Bóg, który chce zawsze dobra człowieka, pobudza odpowiednich ludzi, w tym także i gnostyka ${ }^{57}$, obdarzonego zdolnością niesienia pomocy bliźniemu ${ }^{58}$, aby w sposób pożyteczny realizował to, co zmierza do cnoty ${ }^{59}$.

${ }^{51}$ Por. Strom. I 34, 4, GCS 52, s. 29.

${ }^{52}$ Por. Strom. VI 96, 3, GCS 52, s. 480.

${ }^{53}$ Por. Strom. IV 123, 2, GCS 52, s. 303.

${ }^{54}$ Strom. V 31, 2, GCS 52, s. 347, Kobierce, t. 2, s. 28.

${ }^{55}$ Strom. I 98, 4, GCS 52, s. 65, Kobierce, t. 1, s. 72.

${ }^{56}$ Por. F. van der Grinten, Die natürliche und übernatürliche Begründung des Tugendlebens bei Clemens Alexandrinus, Roma-Berlin 1949, s. 119: „Die christliche Tugend ist bei Klemens begründet in der tatsächlichen Einheit von Natur und Übernatur".

${ }^{57}$ Por. Strom. VII 16, 1, GCS 17, s. 12.

${ }^{58}$ Por. Strom. VI 161, 1, GCS 52, s. 514.

${ }^{59}$ Por. Strom. VI 158, 3-4, GCS 52, s. 513. Por. także C. Nardi, Il Battesimo in Clemente Alessandrino. Interpretazione di Eclogae propheticae 1-26, Roma 1984, s. 141. 


\section{„Gnostyk niesie pomoc bliźniemu”}

Klemens nazywa gnostykiem ${ }^{60}$ tego, który dzięki uczeniu się i badaniu ${ }^{61}$ doszedł do wszechstronnego poznania nauki chrześcijańskiej, czyli gnozy ${ }^{62}$, zaś przez równolegle towarzyszący doskonaleniu intelektualnemu proces doskonalenia moralnego ${ }^{63}$, przez posłuszeństwo przykazaniom i ćwiczeniu się w dobrym, wzniósł się do agape ${ }^{64}$, a więc do harmonii w sprawach przynależnych do kręgu intelektualnego, moralnego i egzystencjalnego, upodabniając się tym samym w jakimś stopniu do Boskiego Logosu, będącego Boską Cnotą - doskonałą harmonią wspomnianych kręgów. Krótko mówiąc, gnostyk jest tym, który nabył cnotę ${ }^{65}$, czyli uzyskał wymagającą nieustannego udoskonalania ${ }^{66}$ jednomyślność z jej niedoścignionym wzorem - Boską Cnotą ${ }^{67}$.

Rolę gnostyka współdziałającego w trudzie nabywania przez człowieka cnoty, jako tego, który nieustannie wsłuchuje się w głos Boskiego Nauczyciela, przemawiającego na kartach obu Testamentów, i poucza swoich braci na wzór Boskiego $\operatorname{Logosu}^{68}$, określa Klemens w następujących słowach:

${ }^{60}$ Wśród licznych publikacji podejmujących zagadnienie gnostyka należy wymienić, poza monumentalnym dziełem W. Völkera, Der wahre Gnostiker ...., następujące prace: P. Dudon, Le gnostique de Saint Clément d' Alexandrie, Paris 1930; P. Th. Camelot, Foi et gnose. Introduction à l'étude de la connaissance mystique chez Clément d'Alexandrie, Paris 1945; P. Brezzi, La gnosi Cristiana di Alessandria e le antiche scuole Cristiani, Milano 1950; C. Guasco, Lo gnostico cristiano Clemente Alessandrino, „Sophia” 26 : 1956, s. 262-269; R. Wagner, Die Gnosis von Alexandria, Stuttgart 1961, s. 104-134; O. Prunet, La morale de Clément d'Alexandrie, Paris 1966; F. Ch. Baur, Die christliche Gnosis, Darmstadt 1967; J. L. Kovacs, Clement of Alexandria and the Vallentinian Gnostics, New York 1978; J. Grzywaczewski, Obraz gnostyka wedlug „Stromatów” Klemensa Aleksandryjskiego, „Vox Patrum” 6 : 1986, z. 11, s. 543-553. Niektórzy badacze twierdzą, że przedstawiony przez Klemensa obraz doskonałego gnostyka był o wiele bliższy obrazowi mędrca stoickiego, niż ideałowi chrześcijanina ukazanemu w Nowym Testamencie. P. Evdokomov, Poznanie Boga w tradycji wschodniej. Patrystyka, liturgia, ikonografia, thum. A. Liduchowska, Kraków 1996, s. 43, pisze bowiem: „gnostycy Klemensa tworzą krąg niemal hermetyczny, są to wybrani, trwający w nieprzerwanym zjednoczeniu z Bogiem. W opisie Klemensa, nie są to rzeczywiście istoty ludzkie, ale raczej postacie fikcyjne, utopia w stylu Platona".

${ }^{61}$ Por. F. Drączkowski, Dowartościowanie kultury intelektualnej przez Klemensa Aleksandryjskiego jako rezultat polemiki antyheretyckiej, „Studia Pelplińskie” 6 : 1975, s. 177-199.

${ }^{62}$ Por. J. Lebreton, La théologie de la Trinité chez Clément d'Alexandrie, „Recherches de science religieuse" 34 : 1947, s. 57; R. Wilson, Gnosis and the New Testament, Oxford 1968, s. 11-12.

${ }^{63}$ Por. Strom. VII 102, 1, GCS 17, s. 72.

${ }^{64}$ Por. F. Drączkowski, Kościót-Agape..., s. 55-56; M. Berciano, Kairós..., s. 210; J. Wytzes, The twofold way II. Platonic influences in the work of Clement of Alexandria, ,Vigiliae christianae” 14 : 1960, s. 139; P. Th. Camelot, Foi et gnoje..., s. 125.

${ }^{65}$ Por. Strom. VII 64, 6, GCS 17, s. 46.

${ }^{66}$ F. Drączkowski mówi tu o stałym procesie wychowania intelektualnego i moralnego. Por. F. Drączkowski, Kościól-Agape..., s. 63.

${ }^{67}$ Por. F. Baravalle, Il concepto di „Homoiosis Theo ” in Clemente Alessandrino, Toronto 1952, s. 88.

${ }^{68}$ Por. Strom. VII 52, 2-53, 1, GCS 17, s. 39. Por. J. Grzywaczwski, Katecheza podstawa rozwoju agape wedtug Klemensa Aleksandryjskiego, „Vox Patrum” 10 : 1990, z. 18, s. 62. 
Ten, który wiedzę o Bogu otrzymał w sposób przejrzysty, pouczony przez mistyczny chór samej

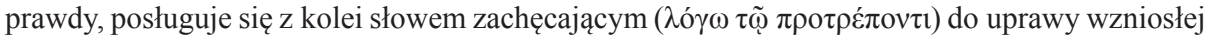
cnoty oraz ukazującym ją samą wedle jej wartości, a także skutki jej działania ${ }^{69}$.

Z przytoczonego cytatu wynika przede wszystkim, że gnostyk, a więc ten, który nabył cnotę za pomocą zachęcającego słowa, którego treść stanowi ukazanie wartości cnoty oraz skutków jej działania ${ }^{70}$, stara się przekonać człowieka do podjęcia wysiłków mających na celu jej osiągnięcie. Stwierdzenie to wymaga jednak uzupełnienia. Użyte bowiem przez Klemensa wyrażenie $\lambda o ́ \gamma \omega ~ \tau \tilde{~}$ chodzi o przekaz w formie ustnej, czy też pisanej ${ }^{71}$. Zastosowanie z kolei w nim

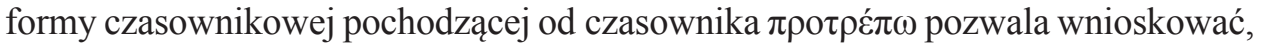
iż działalność tę należy utożsamiać nie tyle z zachętą, ile raczej z pobudzaniem, przynaglaniem i nakłanianiem ${ }^{72}$. Za przesunięciem punktu ciężkości z zachęty na działania bardziej stanowcze zdaje się przemawiać osobiste przekonanie gnostyka o wartości, jaką stanowi cnota, jak również świadomość skutków jej działania widocznych w jego życiu. Co więcej, można przypuszczać, iż tego rodzaju intensyfikacja działań daje działającemu przekonanie o większej ich skuteczności. Niewątpliwie, co warto podkreślić, działania te, odczytane jako pobudzanie, przynaglanie i nakłanianie, należy uznać za wyraz pomocy okazywanej przez gnostyka wszystkim zainteresowanym nabywaniem cnoty. Zdają się one bowiem stanowić nierzadko istotny impuls mobilizujący do podejmowania stosownych działań, zarówno przez rozpoczynających jej nabywanie, jak i tych, którzy z różnych powodów zaprzestali kształtowania swojej osobowości na wzór Boskiego Logosu - Chrystusa.

Wypada ponadto dodać, że o skuteczności tego rodzaju działań decyduje w dużej mierze stopień wiarygodności, jaki przypisuje się osobie działającej. Warto więc podkreślić, iż o wiarygodności gnostyka świadczy przede wszystkim to, że dla dążącego do cnoty jest on świadkiem, który nabył cnotę ${ }^{73}$, a tym samym zna

${ }^{69}$ Strom. VII 45, 1, GCS 17, s. 34, Kobierce, t. 2, s. 253. Por. F. Drączkowski, Kerygmat pisemny w teorii i praktyce Klemensa Aleksandryjskiego, ,Roczniki Teologiczno-Kanoniczne” 26 : 1979, z. 6, s. 21.

${ }^{70}$ Por. Strom. VII 65, 1-4, GCS 17, s. 46-47.

${ }^{71}$ Semantyka terminu $\lambda o ́ \gamma o \varsigma$ dopuszcza jedno i drugie znaczenie. Por. Abramowiczówna, t. 3, s. 45-46. H. von Campenhausen, Ojcowie Kościoła, tłum. K. Wierszyłowski, Warszawa 1998, s. 35, przypisuje Klemensowi rolę nauczyciela i pośrednika w dojściu do doskonałości i utrzymuje, że Klemens ostatecznie uważa, że rzeczywiste poznanie prawdy winno być osiągnięte osobiście, a stąd i nauczanie prawdy winno się odbywać osobiście. To ma być zachętą do wybierania sobie takich nauczycieli, którzy prowadzą do osiągnięcia doskonałości. Jeśli to twierdzenie jest słuszne, to zapewne Klemens spełniał przy swej działalności pisarskiej rolę takiego nauczyciela. Por. J. Wojtczak, Stosunek Klemensa Aleksandryjskiego do filozofii wedlug ,,Stromata”, „Studia Theologica Varsaviensia” 9 : 1971, nr 1, s. 287. Tym samym zaś krąg wychowujących do cnoty należałoby poszerzyć o tych wszystkich, którzy uprawiali kerygmat pisemny.

${ }^{72}$ Por. Abramowiczówna, t. 3, s. 744.

${ }^{73}$ Ponieważ cnota jest wartością dynamiczną, dlatego też gnostyk będący w jej posiadaniu nieustannie zabiega o pełniejsze poznanie Boga-Agape i coraz to doskonalsze upodobnienie się do Niego. Por. Paed. III 1, 1, SCh 158, s. 12, gdzie na uwagę zasługuje wyrażenie $\dot{\varepsilon} \xi o \mu o ı v ̃ \tau \alpha ~ \tau \tilde{\omega} \theta \varepsilon \tilde{\omega}$, które W. Völker, 
drogę do jej osiągnięcia. Poza tym, co podkreśla Klemens w cytowanej powyżej wypowiedzi, a co w istotny sposób uwiarygodnia gnostyka jako świadka, a zarazem pomocnika w nabywaniu cnoty, gnostyk jest tym, który otrzymawszy wiedzę o Bogu $^{74}$ za pośrednictwem mistycznego chóru samej prawdy, czyli kontemplacji ${ }^{75}$, posługuje się z kolei słowem zachęcającym do uprawy wzniosłej cnoty. Znaczy to, że u podstaw omawianej działalności gnostyka, jak nieustannego udoskonalania nabytej przez niego cnoty, leży wiedza o Bogu ${ }^{76}$, a więc o tym, który jako Agape ${ }^{77}$ jest doskonałą harmonią całej egzystencji ${ }^{78}$, a więc poniekąd sfery egzystencjalnej, moralnej i intelektualnej.

Wiarygodność gnostyka jako pomocnika w nabywaniu cnoty, będącego w posiadaniu zarówno jej samej, jak i w pełni wiarygodnej, a zarazem najpełniejszej, bo otrzymanej dzięki kontemplacji, a więc obcowaniu z Bogiem-Agape, szeroko pojętej wiedzy o cnocie, czyli o zharmonizowaniu sfery egzystencjalnej, moralnej i intelektualnej, dopełnia fakt nazwania go przez Klemensa tym, który dzięki nauczaniu słowem i czynem staje się ,„pośrednikiem ( $\alpha v \alpha \delta \varepsilon \xi \hat{\alpha} \mu \varepsilon v o \varsigma)$ w nawiązywaniu ścisłej spójni

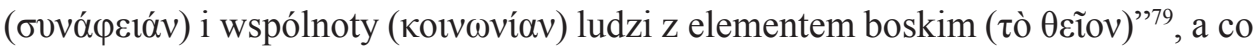

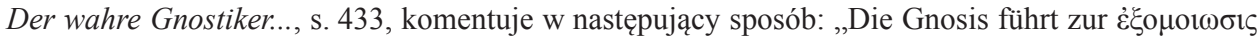
mit Gott, się macht den Gläubingen zum wahren Pneumatiker, durchdringt ihn innerlich eröffnet ihm

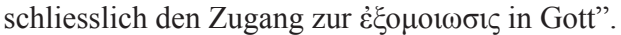

${ }^{74}$ Por. Strom. VII 17, 1, GCS 17, s. 12.

${ }^{75}$ J. Grzywaczewski, Obraz gnostyka ..., s. 546, podkreśla, iż gnostyk posiada niedostępną dla innych wiedzę, zdobytą nie przez studia, lecz dzięki obcowaniu z Bogiem. Potwierdzeniem tego jest wyrażenie o otrzymaniu wiedzy za pośrednictwem mistycznego chóru samej prawdy. Co więcej, użyty w tym wyrażeniu zwrot „mistyczny chór samej prawdy” zdaje się nawiązywać do Platońskiego wyrażenia „boski chór” (Platon, Phaedrus, 247), którym posłużył się Klemens dla określenia wzniosłości kontemplacyjnego obcowania z Bogiem. Por. J. Grzywaczewski, Pojęcie kontemplacji u Klemensa Aleksandryjskiego, „Studia Theologica Varsaviensia” $28: 1990$, nr 1, s. 220. To zaś prowadzi do wniosku, że otrzymanie wiedzy o Bogu za pośrednictwem mistycznego chóru prawdy oznacza jej nabycie na drodze kontemplacji. Zdaniem J. Grzywaczewskiego, Pojęcie kontemplacji..., s. 216, kontemplacja jawi się jako dopełnienie gnozy. Dzięki niej bowiem zwiększa się poznanie Boga. Chrześcijanin oddający się kontemplacji ogląda Boga, poznaje Go, a jednocześnie uzyskuje głębsze zrozumienie wielu tajemnic, które nie są dostępne rozumowi ani badaniu czysto naukowemu. W tym znaczeniu ogląd mistyczny może stanowić źródło prawdziwego, dogłębnego poznania (gnosis). Ogląd taki daje w jakimś stopniu udział w Bożej wiedzy. Por. tenże, Terminologia kontemplacji w dziełach Klemensa Aleksandryjskiego, ,, Roczniki Teologiczno-Kanoniczne” 40 : 1993, z. 4, s. 160-161. Na temat kontemplacji u Klemensa zob. także: tenże, O kontemplacji w ujęciu św. Klemensa Aleksandryjskiego, Niepokalanów 1993; H. Wójtowicz, Kontemplacja i działanie u Klemensa Aleksandryjskiego, „Kronika Diecezji Sandomierskiej” 74 : 1981, s. 82-85; tenże, Kontemplacja i działanie u Ojców Kościoła, [w:] Kontemplacja i działanie, red. W. Słomka, Homo Meditans 2, Lublin 1984, s. 63-68.

${ }^{76}$ Wiedza o Bogu, a więc i o Boskim Logosie - Chrystusie nie sprowadza się jedynie do informacji ontologicznych, ale dotyczy przede wszystkim Jego oczekiwań wobec człowieka realizującego konkretny model życia moralnego, prowadzący do osiągnięcia cnoty. Innymi słowy, chodzi o wiedzę na temat tego, co dobre i złe dla człowieka dążącego do cnoty.

${ }_{77}$ Por. $1 \mathrm{~J} 4,16$.

${ }^{78}$ Por. F. Drączkowski, Kościót-Agape..., s. 71.

${ }^{79}$ Strom. VII, 52, 1, GCS 17, s. 38, Kobierce, t. 2, s. 259. 
za tym idzie, także gwarantem ${ }^{80}$ osiągnięcia cnoty. Przytoczone tu słowa, mówiące o pośrednictwie gnostyka dokonującym się w pierwszym rzędzie dzięki pouczaniu słowem dążącego do cnoty, stanowiące zarazem istotne dopowiedzenie do wcześniejszej wypowiedzi Klemensa ${ }^{81}$, bo rozwijające kwestię pouczania słownego, należy rozumieć przede wszystkim jako pouczenie gnostyka - mającego, dzięki kontemplacji, pełną wiedzę o cnocie ${ }^{82}$ - o niemożliwości nabycia przez człowieka cnoty tożsamej z Boską Cnotą ${ }^{83}$. Człowiek bowiem, jak zdaje się przekonywać gnostyk, choćby zdobył możliwie jak najdoskonalszą cnotę, to w odniesieniu do jej wzoru - Chrystusa, uosabiającego poprzez wydarzenie wcielenia Boga-Agape ${ }^{84}$, zdobywa zawsze jedynie jakąś jej część czy element. Ludzka cnota odzwierciedla zatem jedynie małą część Boskiej Cnoty. Oznacza to obecność w człowieku jedynie małego jej fragmentu, będącego, o ile można tak powiedzieć, jedynie jakimś elementem boskości ${ }^{85}$, co trafnie wydaje się oddawać obecny w przytoczonej wypowiedzi

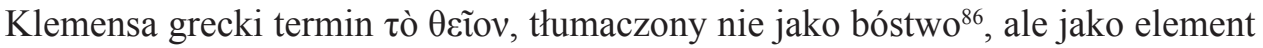
boski ${ }^{87}$. Fakt ten nie powinien jednak nikogo zniechęcać do jej nabywania. Nabyta bowiem cnota, będąca jedynie cząstką Cnoty Boskiej, stanowi dla człowieka wielką wartość. Choć bowiem nie odzwierciedli ona nigdy w pełni swego pierwowzoru,

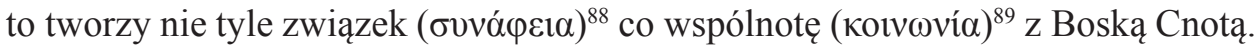
Wypada zatem raz jeszcze stwierdzić, iż pouczenia słowne gnostyka - „świadka” cnoty stanowią istotną pomoc dla zmagającego się z szeroko pojętym trudem, towarzyszącym jej nabywaniu. Mające, jak się wydaje, mobilizująco-informacyjny charakter pouczenia, powinny bowiem, jak to już zostało wcześniej zasygnalizowane, zachęcać do podejmowania stosownych działań prowadzących do osiągnięcia cnoty, a także ustrzec przed rezygnacją z dalszych zabiegów o nią, wszystkich zniechęconych brakiem oczekiwanych rezultatów wiernego odzwierciedlenia jej pierwowzoru.

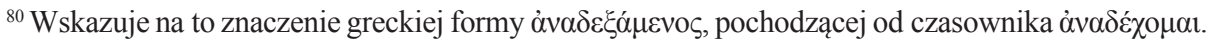
Por. Abramowiczówna, t. 1, s. 138.

${ }^{81}$ Por. Strom. VII 45, 1, GCS 17, s. 34.

${ }^{82}$ Por. Strom. VII 4, 2, GCS 17, s. 5.

${ }^{83}$ Por. Strom. VII 88, 6, GCS 52, s. 476.

${ }^{84}$ Por. QDS 37, 1, GCS 39, s. 183. Bóg, który jest agape, w Jezusie Chrystusie objawia swoją istotę. Por. W. Breuning, Nauka o Bogu, tłum. J. Fenrychowa, [w: ] Podręcznik teologii dogmatycznej w jedenastu traktatach, red. W. Beinert, Kraków 1999, s. 33.

${ }^{85}$ Można by zaryzykować stwierdzenie, że ten, kto nabył cnotę, nosi w jakimś sensie w sobie Boga. Por. K. Rudolph, Die Gnosis, Leipzig 1980, 98-102. Wypada jednak dodać, iż stwierdzenie to może wydawać się bliskie przedstawicielom gnozy niechrześcijańskiej, którzy utrzymywali, że człowiek pneumatyczny, czyli gnostyk, jest prawie równy Bogu, czemu stanowczo sprzeciwiał się Klemens, utrzymując, że pomiędzy człowiekiem a Bogiem istnieje zawsze dystans. Por. F. van der Grinten, Die natürliche und übernatürliche Begründung des Tugendlebens bei Clemens Alexandrinus, Roma-Berlin 1949, s. 119.

${ }^{86}$ Por. Abramowiczówna, t. 2, s. 446.

${ }^{87}$ Por. Kobierce, t. 2, s. 259.

${ }^{88}$ Por. Abramowiczówna, t. 4, s. 192.

${ }^{89}$ Por. tamże, t. 2, s. 685. 
Świadomość faktu, że cnota człowieka pozostanie zawsze czymś innym niż Cnota Boga, a tym samym jako całość będzie jedynie czymś Boskim w człowieku ${ }^{90}$, nie zniechęca gnostyka w nieustannym doskonaleniu się na wzór Boskiej Cnoty. Dbając więc o rozwój sfery intelektualnej, mającej zaowocować osiągnięciem gnozy, dającej tym samym harmonię i jedność z Bożym umysłem w zakresie spraw przynależnych do sfery intelektualnej, „trwa on do późnego wieku w badaniu Pisma Świętego oraz „trwa on do późnego wieku w badaniu Pisma Świętego"91, czego rezultatem jest niepełne poznanie prawdziwej mądrości Bożej, mobilizujące nieustannie do przyswajania sobie pełnej wiedzy i mądrości Bożej poprzez lekturę słowa Bożego ${ }^{92}$. Wraz z kształceniem umysłu zabiega gnostyk także o doskonalenie sfery moralno-egzystencjalnej ${ }^{93}$. Jak bowiem pisze Klemens, wstrzymuje się on zgodnie z prawem od złych czynów i myśli ${ }^{94}$, a tym samym wypełnia przykazania zawarte w Ewangelii ${ }^{95}$. Wszystkich tych działań podejmuje się z przekonaniem, iż dzięki nabytej tą drogą cnocie, osiągnie wspólnotę z samym Bogiem ${ }^{96}$. Co więcej, potwierdzając życiem pouczenia słowne ${ }^{97}$, aktywizuje on tym samym do działania zarówno mających zamiar wejść na drogę cnoty, jak i tych, którzy zmagają się z towarzyszącym jej nabywaniu trudem.

Omawiana rola gnostyka wobec tych, którzy mają zamiar zabiegać o cnotę, bądź podążają już jej drogą, nie ogranicza się jedynie do zachęty, podtrzymywania w trudnościach, czy też podnoszenia na duchu zachętą i podnietą ${ }^{98}$. Gnostyk, jak mówi bowiem Klemens, „otrzymawszy od Boga zdolność niesienia przysługi, niesie pomoc bliźniemu albo przez towarzyszenie, wdrażając go do właściwej postawy, albo zachęcając go do naśladowania siebie, albo też wychowując i pouczając rozkazem"99.

Powyższa wypowiedź, osadzona w kontekście pomocy na korzyść życia ${ }^{100}$ utożsamianego z życiem wiecznym, będącym owocem cnoty ${ }^{101}$, zawiera ważne stwierdzenie, wyraźnie poszerzające zakres pomocy świadczonej przez gnostyka temu, kto rozpoczyna proces nabywania cnoty. Aleksandryjczyk wśród sposobów okazywania owej pomocy wymienia bowiem na pierwszym miejscu czynność towarzyszenia, używając na jej wyrażenie formy $\pi \alpha \rho \alpha \kappa o \lambda o v \theta \eta ́ \sigma \varepsilon ı$, pochodzącej

${ }^{90}$ Por. Strom. VI 125, 5, GCS 52, s. 495.

${ }^{91}$ Strom. VII 104, 1, GCS 17, s. 73, Kobierce, t. 2, s. 303.

${ }^{92}$ Por. F. Drączkowski, „Miłować Boga całym umystem” "w interpretacji Klemensa Aleksandryjskiego, „Vox Patrum” 8 : 1988, z. 15, s. 605, 613-614.

${ }^{93}$ Por. tenże, Klemens Aleksandryjski-pedagog oświeconych, „Ateneum Kapłańskie” 93 : 1979, s. 32.

${ }^{94}$ Por. Strom. VII 76, 1, GCS 17, s. 54.

${ }^{95}$ Por. Strom. VII 76, 4, GCS 17, s. 54.

${ }^{96}$ Por. Strom. VII 48, 6-7, GCS 17, s. 36.

${ }^{97}$ Por. Strom. VII 53, 1, GCS 17, s. 39.

${ }^{98}$ Por. Strom. VII 69, 2, GCS 17, s. 49.

${ }_{99}^{9}$ Strom. VI 161, 1, GCS 52, s. 514, Kobierce, t. 2, s. 210.

${ }^{100}$ Por. Strom. VI 161, 6, GCS 17, s. 515.

${ }^{101}$ Por. Strom. IV 36, 5, GCS 52, s. 264. 
od czasownika $\pi \alpha \rho \alpha \kappa o \lambda o v \theta \eta ́ \omega$, który oprócz wspomnianego towarzyszenia, może oznaczać także: śledzić coś uważnie, słuchać pojętnie, pojmować, rozumieć102. Wydaje się zatem, iż w czynność towarzyszenia, rozumianą jako nieustanną wręcz obecność przy noszącym się z zamiarem nabywania cnoty, wpisana jest także, ważna skądinąd, umiejętnością słuchania, dająca gnostykowi możliwość poznania i zrozumienia szeroko pojętej kondycji moralno-intelektualnej bliźniego ${ }^{103}$, mająca istotny wpływ na charakter działań wdrażających do nabywania cnoty. Bezsprzecznie, postawa taka, będąca przejawem autentycznej chęci niesienia pomocy, której obce wydaje się być przedmiotowe traktowanie bliźniego, pozwala widzieć w gnostyku niezawodnego pomocnika w całym procesie nabywania cnoty.

Gnostyk, o czym mowa jest w powyższej wypowiedzi Klemensa, niesie pomoc zainteresowanym nabywaniem cnoty, współdziałając tym samym w trudzie jej nabywania także poprzez zachętę do naśladowania samego siebie, do czego upoważnia go z pewnością osiągnięty na miarę ludzkich możliwości, stale udoskonalany stopień podobieństwa do Boskiej Cnoty ${ }^{104}$. Naśladowanie to oznacza zaś podążanie drogą będącą przekonywującym świadectwem możliwości nabycia przez człowieka nieosiągalnej, jakby się wydawało, cnoty, w którą to drogę wpisane zostały tym samym sposoby przezwyciężania szeroko pojętego trudu towarzyszącego jej zdobywaniu, a także strategia podjętych przez gnostyka działań, gwarantujących rozwój i harmonię z Boską Cnotą sfery intelektualnej, moralnej i egzystencjalnej człowieka. Ten rodzaj pomocy, będący głównie wzorcem zachowań gwarantujących nabycie cnoty, dopełnia rozkaz mający na celu pouczenie i wychowanie, a więc niejako właściwe ukierunkowanie dalszych działań tych, u których brak wyraźnych efektów kształtowania uporząakowanej osobowości. Świadczona w ten sposób pomoc, jak i wcześniejsze - towarzyszenie oraz zachęta do naśladowania, są wyrazem troski gnostyka o doskonałość bliźniego, do czego został on zobowiązany Bożym nakazem działania ${ }^{105}$.

Mówiąc o pomocy gnostyka świadczonej kształtującemu na miarę ludzkich możliwości uporządkowaną osobowość, należy wspomnieć także o modlitwie, jaką zanosi on do Boga, świadom konieczności oddziaływania na innych ludzi, znajdujących się na niższych szczeblach rozwoju wewnętrznego ${ }^{106}$. Modlitwą tą ogarnia gnostyk zarówno sprawiedliwych, jak i tych, którzy co prawda dążą do Boga, lecz są słabi. W szczególny zaś sposób prosi o powrót do sprawiedliwości ze strony znieczulonych, czyli żyjących w grzechu ${ }^{107}$.

\footnotetext{
${ }^{102}$ Por. Abramowiczówna, t. 3, s. 405.

${ }^{103}$ Por. Strom. VII 4, 2, GCS 17, s. 5.

${ }^{104}$ Por. Paed. I 100, 3, SCh 70, s. 288.

${ }^{105}$ Por. Strom. VII 3, 4, GCS 17, s. 4.

${ }^{106}$ Por. $Q D S 40,5$, GCS 17, s. 186-187.

${ }^{107}$ Por. J. Grzywaczewski, Modlitwa blagalna w ujęciu Klemensa Aleksandryjskiego, „Homo Dei” 63: 1994, z. 2, s. 19.
} 
Kończąc powyższe rozważania o współdziałającym w nabywaniu cnoty, należy zauważyć, iż koncentrowały się one wokół postaci gnostyka, doskonałego chrześcijanina, który dzięki nabytej cnocie doszedł do wyjątkowo wysokiego stopnia świętości ${ }^{108}$. Według Klemensa termin „gnostyk” odnieść należy także do apostołów ${ }^{109}$, jak również do biskupów, prezbiterów i diakonów ${ }^{110}$, którzy po ich śmierci przejęli ich działanie i funkcje ${ }^{111}$. W koncepcji naszego Autora oddziaływanie grona apostołów rozciąga się jednak niejako w kategorii czasu aż do współczesności, co pozwala widzieć w owym terminie jeszcze jedną kategorię ludzi. Z powodu dewaluacji terminu ,gnostyk” we współczesnym języku wydaje się, że należałoby zamiast niego użyć takich określeń, jak: „święty”, „przyjaciel Boga”, „doskonały w miłości”, „w pełni doskonały” czy „doskonały chrześcijanin”"112, a tym samym przyjąć, iż do grona współdziałających w nabywaniu cnoty należy każdy ochrzczony, który zobowiązany do trwania w jedności z Bogiem, winien zabiegać o coraz wyższy stopień upodobnienia się do Boskiej wspólnoty życia - Agape. To utożsamianie gnostyka z laikatem wypływa poniekąd z postulatu samego Klemensa, który zalecał, aby biskupi, prezbiterzy oraz diakoni byli wybierani z grona gnostyków ${ }^{113}$. A ponieważ jest rzeczą oczywistą, iż tego rodzaju urzędy mogli piastować tylko nieliczni gnostycy, zatem pozostali powinni tworzyć w Kościele grupę zaangażowanych świeckich, działających w łączności z Chrystusem, jako współformułujący osobowość człowieka. W związku z powyższym można wysunąć postulat o powszechności funkcji współdziałającego w nabywaniu cnoty, która winna być udziałem całego ludu Bożego, czyli Kościoła.

*

Podsumowując treść niniejszego artykułu, wypada raz jeszcze stwierdzić, że proces nabywania cnoty, rozumianej, krótko mówiąc, jako kształtowanie na wzór Chrystusa uporządkowanej osobowości, wiąże się, jak wykazała to analiza pism Klemensa, z niemałym trudem. Wynika on głównie z konieczności podążania drogą Bożych przykazań, a także pokonywania zniechęcenia, jakie rodzi nieustanna wierność Bożym poleceniom, długotrwały proces nabywania cnoty, przekonanie o niemożliwości jej nabycia oraz podejmowanie, zaprzestanych z różnych powodów, koniecznych

${ }^{108}$ Por. A. Brontesi, La soteria in Clemente Alessandrino, Roma 1972, s. 421-422, 474; W. Völker, Der wahre Gnostiker...., s. 420. Świętość ta polegała na tym, że „bez żadnego zaniedbania i w sposób świadomy wypełnił wszystko, co do niego należało, i w zakresie przyswojenia sobie wiadomości i w zakresie opanowania siebie, i w zakresie pełnienia dobrych uczynków" (Strom. VII 48, 6-7, GCS 17, s. 36, Kobierce, t. 2, s. 256).

${ }^{109}$ Strom. IV 75, 1, GCS 12, s. 268. Por. Strom. VII 95, 3, GCS 17, s. 67; III 109, 3, GCS 52, s. 247.

${ }^{110}$ Por. Strom. VI 107, 2, GCS 52, s. 485.

111 Strom. VI 106, 1, GCS 52, s. 485, Kobierce, t. 2, s. 175.

${ }^{112}$ Por. F. Drączkowski, Powszechność funkcji keryksa w Kościele starożytnym. Stanowisko Klemensa Aleksandryjskiego, „Vox Patrum” 22: 2002, t. 42-43, s. 111; J. Grzywaczewski, Katecheza podstawa rozwoju agape wedtug Klemensa Aleksandryjskiego, „Vox Patrum” 10 : 1990, z. 18, s. 62.

${ }^{113}$ Strom. VI 107, 3, GCS 52, s. 486, Kobierce, t. 2, s. 176. 
działań prowadzących do jej osiągnięcia. Skuteczną pomoc w pokonywaniu tak rozumianego trudu może okazać zainteresowanemu nabywaniem cnoty gnostyk, który przez osiągnięcie na miarę swych ludzkich możliwości stale udoskonalanej cnoty, staje się wiarygodnym świadkiem, a jednocześnie wzorcem zachowań, dającym przekonujące świadectwo możliwości jej nabycia, a zarazem mobilizującym do nieustannego podejmowania stosownych działań, gwarantujących jej osiągnięcie i rozwój. Przejawem współdziałania gnostyka w trudzie nabywania cnoty są także jego pouczenia słowne, których informacyjno-mobilizujący charakter stanowi nie tylko istotny impuls do wejścia na drogę prowadzącą do cnoty i podążania nią, ale ma także ustrzec przed rezygnacją z zabiegów o cnotę wszystkich zniechęconych brakiem widocznych efektów w odzwierciedlaniu jej pierwowzoru. Co więcej, gnostyk stara się także poznać kondycję moralno-intelektualną rozpoczynających nabywanie cnoty, warunkującą charakter działań wdrażających do procesu jej nabywania. Ten rodzaj świadczonej pomocy pozwala z kolei widzieć w nim niezawodnego pomocnika w całym procesie kształtowania jak najdoskonalszej cnoty. Innym rodzajem pomocy będącej wyrazem współdziałania w trudzie jej nabywania jest rozkaz, mający przynieść właściwe ukierunkowanie działań, prowadzących do uzyskania wymiernych efektów procesu kształtowania cnoty, a także modlitwa, którą gnostyk obejmuje wszystkich dążących do doskonałości. Tak zarysowany obszar działań odnieść należy nie tyle do gnostyka, ile do całego ludu Bożego, którego członkowie - przyjaciele Boga, zobowiązani na mocy chrztu św. do nieustannego pogłębiania swej łączności z Chrystusem, winni także nieść pomoc wszystkim zainteresowanym nabyciem jak najdoskonalszej cnoty, czyli w pełni uporządkowanej osobowości.

\section{Summary}

\section{Friends of God (Gnostics) - collaborating in the toil of acquiring virtue contribution to the aretology of Clement of Alexandria}

Acquiring virtue, understood as a well-ordered personality, is connected with a considerable toil, as follows from the writings of Clement from Alexandria. Its source is to be ascribed, first of all, to the necessity of being true to God's commandments, but also to overcoming discouragement caused by: the long-lasting process of its acquiring, the conviction of impossibility to achieve it, undertaking yet again the ceased "moral cultivation" or other appropriate actions not infrequently given up under the influence of the opinion of the environment. Therefore, the one who acquires virtue, is supported by a gnostic, a perfect Christian, filled with concern for others, who, thanks to his acquired and constantly perfected virtue, becomes - both, for those who intend undertaking the toil of its acquiring, and those who walk the road of virtue - first of all a guarantor of its achievement, encouraging thereby to acquiring it. While being somehow a witness of virtue, he uses in relation to those who strive for it, credible verbal instructions, thus mobilizing those who are discouraged by the toil of acquiring it, to walk the chosen road of virtue. Besides, he tries to discern the moral and intellectual condition of those who begin to acquire virtue, which has an essential influence on the character of the proposed actions that introduce to its acquiring. What's more, an expression of that help is an encouragement to follow 
him, a command and also prayer. However, the help provided this way should be a contribution not so much of the gnostics himself, as of the whole people of God, obliged to holiness on account of the sacrament of baptism.

\section{Keywords}

Aretology, Clement of Alexandria, gnostic, patrology, virtue 